\title{
Associations between Optical Properties and Mixotrophic Ciliates Abundances Using Remote Sensing Techniques in Two North Patagonian Lakes (Villarrica and Caburgua, $38^{\circ} \mathrm{S}$, Araucania, Chile)
}

\author{
Patricio De los Ríos-Escalante ${ }^{1,2 *}$, Ángel Contreras ${ }^{1}$, Gladys Lara ${ }^{1}$, \\ Mirtha Latsague ${ }^{1}$, Carlos Esse ${ }^{3}$ \\ ${ }^{1}$ Departamento de Ciencias Biológicas y Químicas, Facultad de Recursos Naturales, \\ Universidad Católica de Temuco, Casilla 15-D, Temuco, Chile \\ ${ }^{2}$ Núcleo de Estudios Ambientales UC Temuco. \\ ${ }^{3}$ Universidad Autónoma de Chile, Instituto Iberoamericano de Desarrollo Sostenible (IIDS), \\ Unidad de Cambio Climático y Medio Ambiente (UCCMA), Facultad de Arquitectura, \\ Construcción y Medio Ambiente, Avenida Alemania Nº 01090, Temuco, Chile.
}

Received: 1 March 2021

Accepted: 17 June 2021

\begin{abstract}
The north Patagonian lakes in their original stage were characterized by their marked oligotrophy, with high abundance of mixotrophic ciliates in lakes with native forest in their surrounding basins. Nevertheless, in the last decades, it was a replace of native forest of different kind of human activities, such as towns and agricultural zones, that generate a transition from oligotrophy to mesotrophy, being replaced the mixotrophic ciliates by different kind of phytoplankton. The aim of the present study was to propose a descriptive model using remote sensing techniques for determining the best model for predict the mixotrophic ciliates abundance in two North Patagonian Chilean lakes.

In studies sites, only Caburgua lake has mixotrophic ciliates, that belong to the species Ophyridium naumanni, Stentor amethystinus and S. araucanus, whereas Villarrica lake has not mixotrophic ciliates. The multiple regression analysis revealed that for O.naumanni and S. amethystinus have significant direct associations between temperature, B01, B07 reflectances, $S$. araucanus abundances, and inverse associations with B02, B04 and B07, and the abundance of both species was significantly inverse. Finally, for S. araucanus was positive associations with B04 and S. amethystinus. The exposed results would be similar to the first descriptions of mixotrophic ciliates abundances for Argentinean and
\end{abstract}

*e-mail: prios@uct.cl 
Chilean Patagonian lakes. On this basis, we propose the use of remote sensing techniques would be an important key tool for study the presence of these organism.

Keywords: patagonian lakes, spectral properties, mixotrophic ciliates, chlorophyll, remote sensing

\section{Introduction}

The Argentinean North Patagonian lakes originally were described as oligotrophic, and with native forest in their surrounding basins [1,2], these lakes in their original stage would have abundant mixotrophic ciliates [3] specifically of species Ophyridium naumanni, Stentor amethystinus, and S. araucanus that currently are abundant in lakes with low human alterations [4-7]. In opposite scenario, many Chilean north Patagonian lakes have marked human intervention in their surrounding basins, due towns and agricultural zones $[8,9]$, that generate transition from oligotrophy to mesotrophy in a period of two decades [10] with consequent changes in the zooplankton assemblages in function to trophic status even in different bays in the same lake such as was described for Llanquihue lake $\left(41^{\circ} \mathrm{S}\right)[8,9]$.

On the view point of mixotrophic ciliates, these would be abundant under low chlorophyll concentration, that would be associated to low crustacean zooplankton species richness and abundances, and in this scenario mixotrophic ciliates would be indicators of ultraoligotrophic or oligotrophic status in Patagonian lakes [3-5]. But under chlorophyll increase due transition from oligotrophy to mesotrophy mixotrophic ciliates are replaced due predation by crustacean zooplankton species such as Mesocyclops araucanus (= Mesocyclops longisetus) [3, 4, 11, 12]. Also, under original oligotrophic status, the mixotrophic ciliates would graze on bacteria, and simultaneously it has endosymbiontic activity due endosymbiotic algae $[12,13]$ and it would be prey of native juvenile fishes [14]. If it is considered that mixotrophic ciliates are key species as bioindicators in Patagonian lakes with ultraoligotrophic or oligotrophic status, probably the trophic status variations can be detectable using spectral properties by remote sensing techniques [15].

This scenario of trophic gradient of different lakes could be studied using their spectral properties. The scarce studies for Patagonian lakes, involves marked associations between LANDSAT ETM + sensor for obtain optical image properties and zooplankton assemblages in lakes with marked glacier influence that would be associated with natural changes in water colour, such as was observed for General Carrera $\left(46^{\circ} \mathrm{S}\right)$ and Tagua-Tagua $\left(42^{\circ} \mathrm{S}\right)$ lakes [16-18]. In this context, it would be possible found differences between optical properties in lakes with presence and absence of mixotrophic ciliates considering their trophic differences associated [15]. The aim of the present study was determining the potential associations between optical properties obtained by remote sensing techniques and mixotrophic ciliates abundances in two Chilean North Patagonian lakes with presence of mixotrophic ciliates (Caburgua), and absence of mixotrophic ciliates (Villarrica) [15]. The hypothesis of the present study would be that associations between the different kind of mixotrophic ciliates abundances with reflectance values of different bands of LANDSAT/OLI in both mentioned lakes.

\section{Material and Methods}

Study sites: lake Caburgua is located in Andes mountains in Araucania region, its surrounding basin has perennial native forest with mountains, and very few human altered zones, this lake is oligotrophic with marked mixotrophic Stentor protozoa abundances [4, 5] (Table 1, Fig. 1). Lake Villarrica is located at west of Caburgua lake [4], its surrounding basin is characterized by the presence of Villarrica and Pucon towns, small recreational residences at south, native forest at north [15], and the presence of Villarrica volcano (Fig. 1).

Sampling procedures: both sites were visited between November 2018 and January 2019 that is the period with maximum zooplankton abundances [3, 5]. For Caburgua lake, four sites were sampled in a transect of $4 \mathrm{~km}$ at north of the lake (Fig. 1), whereas for Villarrica lake it considered two bays with towns in the south shore (Villarrica and Pucon), one site at center of the lake, and the fourth site in the northern shore of the lake where there is native forest (Fig. 1). For each site was measured in situ temperature using sensor YSI Pro Plus, at surface, concentration of total bacteria $(\mathrm{AMR}=$ aerobic mesophilic recount $)$ were quantified in laboratory [19]. Chorophyll $a$, from samples were analysed using acetone extraction [20], whereas mixotrophic ciliates were quantified and identified based on literature [5, 14].

The spectral properties were obtained from satellite LANDSAT/OLI, it got from Land Processes Distributed Active Archive Center (LP DAAC) from U.S. Geological Survey (http://LPDAAC.usgs.gov). The bands of visible light used were B01 coastal spray (0.430-0.450 $\mu \mathrm{m})$, B02 blue $(0.450-0.510 \mu \mathrm{m})$, B03 green $(0.530-0.590 \mu \mathrm{m}), \mathrm{B} 04$ red $(0.640-0.670 \mu \mathrm{m})$, for near infrared were B05 $(0.850-0.880 \mu \mathrm{m})$, and for short wave infrared (SWIR) were B06 $(1.570-1.650 \mu \mathrm{m})$ and B07 $(2.100-2.290 \mu \mathrm{m})$ were calibrated radiometrically to spectral irradiance and then to reflectance, with atmospheric correction being applied [15-17, 20-22].

Exploratory multivariate data analysis: all data analysis was applied using software R [23]. As first step, data analysis a first step was applied a matrix correlation 


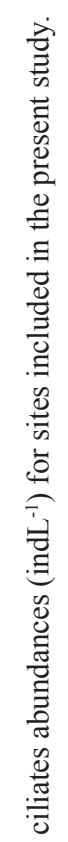

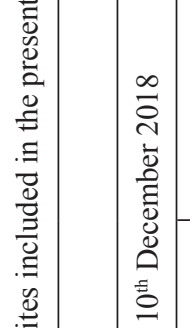

竞

:

른

苟

然

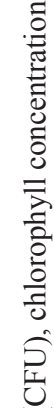

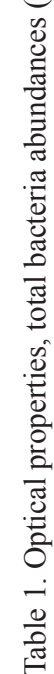

z

:

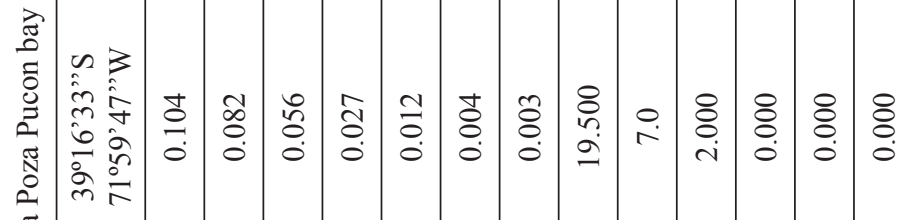

$$
\begin{aligned}
& \text { ป }
\end{aligned}
$$

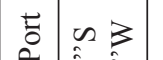

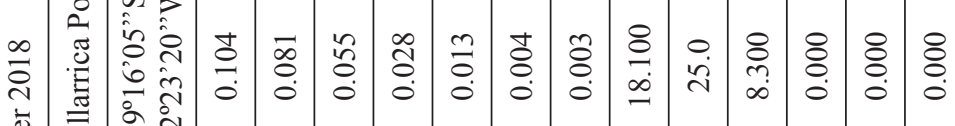
गे

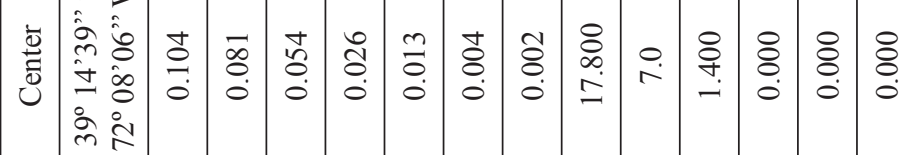

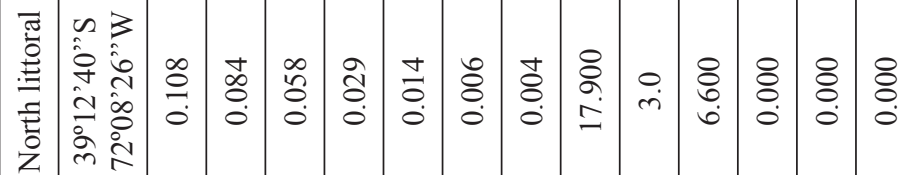

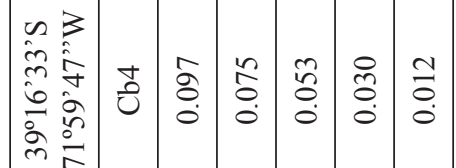

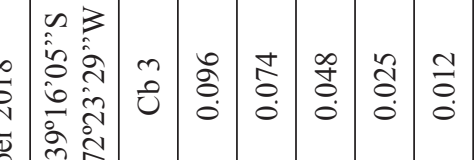
ठั.

๑ั

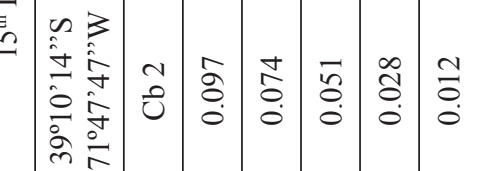

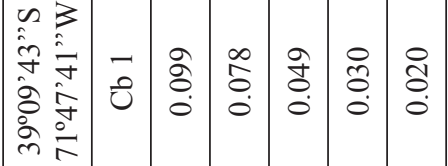

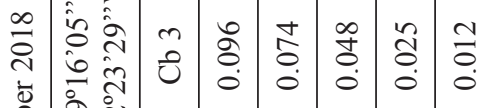

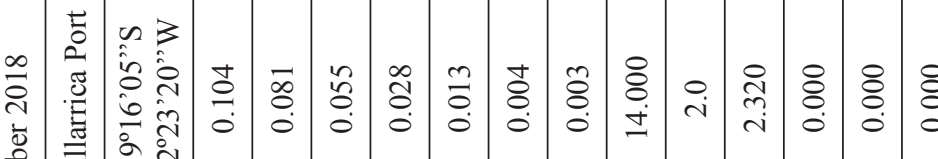

苛焉

音

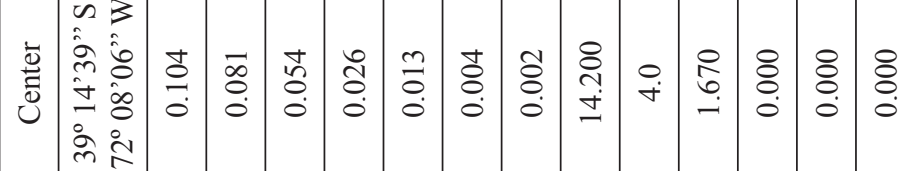

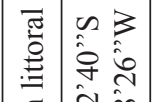

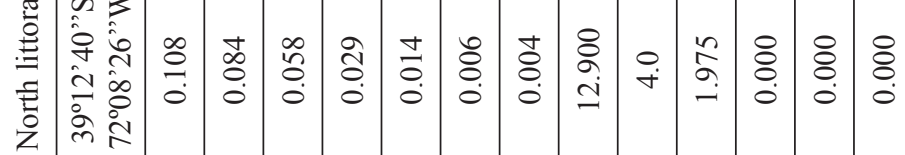

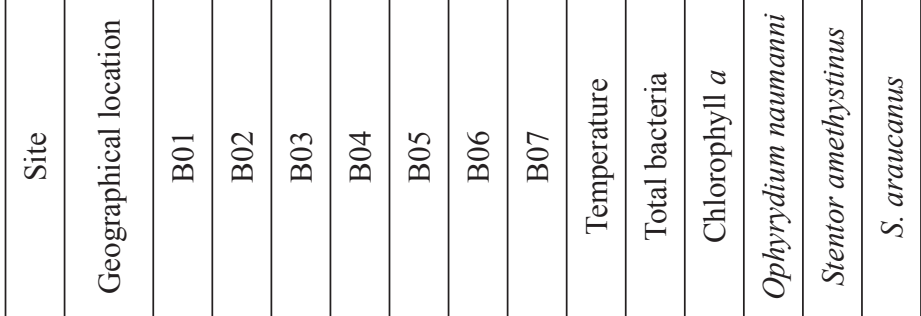

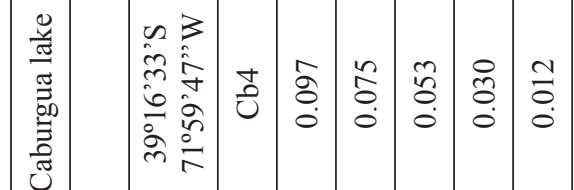

on 3 है

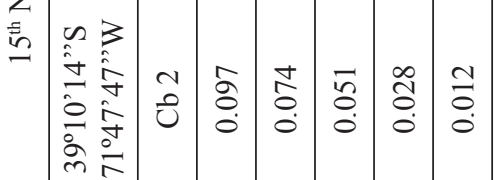

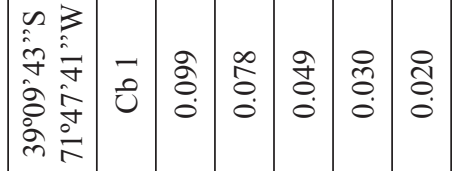

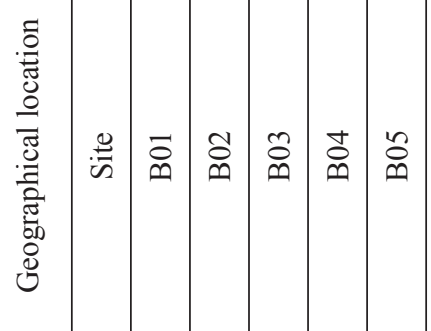




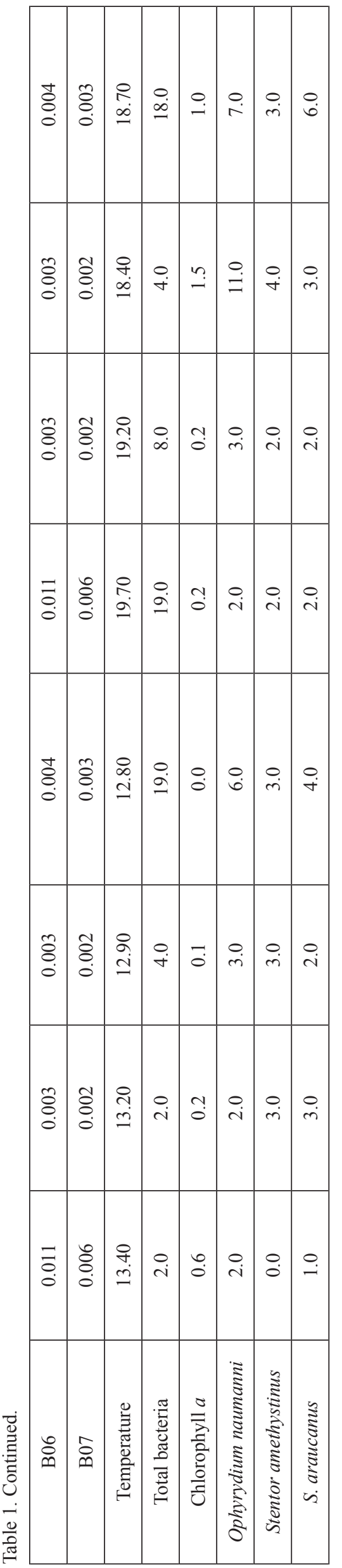

analysis using Hmisc R package [24], for determine the associations between studied variables. As second step a principal component analysis (PCA), this statistical analysis was applied, factoextra [25] and ggplot2 [26] $\mathrm{R}$ packages. As second step, a multiple regression analysis [27] was applied considering as dependent variables, the abundance of the mixotrophic ciliates abundances, and independent variables the optical properties, temperature, chlorophyll a concentration, and bacterial abundances, all data analysis was applied using software R [23].

\section{Results}

The obtained results revealed that chlorophyll concentration and reflectance values of LANDSAT OLI, are more high at Villarrica lake in comparison to Caburgua lake, therefore the mixotrophic ciliates were absent in Villarrica lake (Table 1). The temperature and total bacteria values were not relatively different for studied sites (Table 1).

The correlation matrix revealed the existence of significant direct associations between B01 with B02, B01 with B03, B01 with chlorophyll $a$, B02 with B03, B02 with chlorophyll $a, \mathrm{~B} 03$ with chlorophyll $a, \mathrm{~B} 04$ with B05, B04 with B06, B04 with B07, B05 with B06, B05 with B07, B06 with B07, total mixotrophic ciliates with $O$. naumanni, total mixotrophic ciliates with $S$. amethystinus, total mixotrophic with $S$. araucanus, $O$. naumanni with $S$. amethystinus, O. naumanni with $S$. araucanus and $S$. amethystinus with $S$. araucanus (Table 2). Finally, inverse significant associations were found between B01 with total mixotrophics ciliates, B01 with O. naumanni, B01 with $S$. amethystinus, B01 with araucanus, B02 with total mixotrophics ciliates, B02 with O. naumanni, B02 with $S$. amethystinus, B02 with $S$. araucanus, B03 with total mixotrophics, B03 with $O$. naumanni, B03 with $S$. amethystinus, B03 with $S$. araucanus, and Chlorophyll a with $S$. araucanus (Table 2).

The PCA results revealed that the main contributor variables for axis 1, were B01. B02, total mixotrophic ciliates and $S$. amethystinus, whereas for second axis, the main contributor variables were B05, B06, and B07 (Table 3, Fig. 2). The PCA results revealed the existence of two main group, the first group joined Villarrica lake sites, within these sites, the north littoral sites have high of B01 and B02 reflectances and low chlorophyll $a$ concentration in comparison with other sites of this lake whereas the remaining sites of Villarrica lake have high B03 reflectance and marked high chlorophyll concentration (Fig. 2). A different situation was reported for Caburgua lake, where the first site corresponding to nearby to littoral in both sampled dates was different, because both sites have high B04, B05, B06 and B07 reflectance values, and low mixotrophic abundances considering total mixotrophics ciliates and each recorded species (Fig. 2). Whereas 

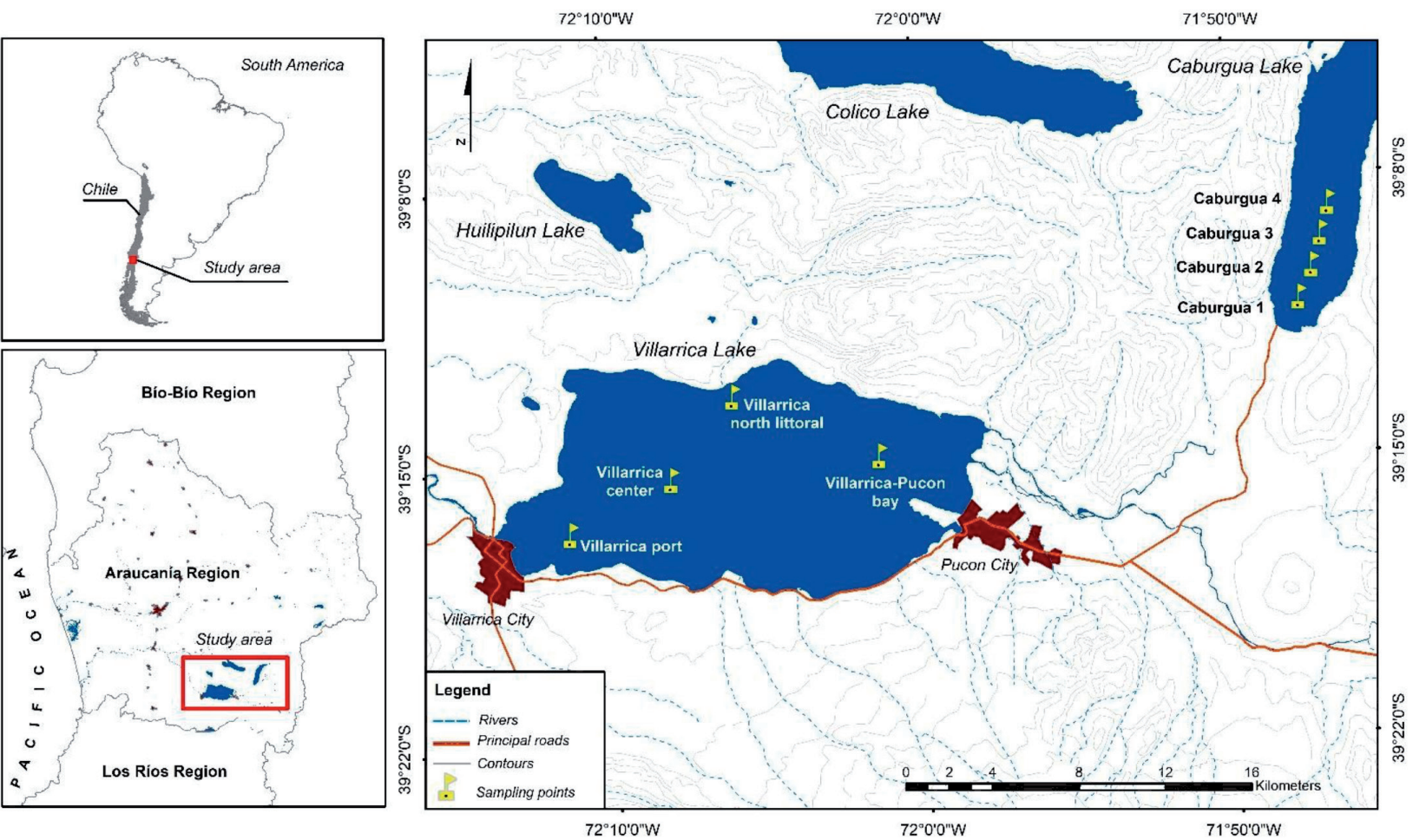

Fig. 1. Map with sites included in the present study [28].

the remaining sites of Caburgua lake that have low reflectance values, and high mixotrophic abundances considering total mixotrophics and each recorded species (Fig. 2).

The results of multiple regression, revealed first that the most robust model for $O$. naumani has direct significant associations with B01 and B07 reflectances, temperature, total mixotrophic ciliates abundances and $S$. araucanus abundances, whereas it has inverse significant association between B02, B04 and B07 reflectances, and with $S$. amethystinus abundances (Table 4). As second step, the results of multiple regression, revealed first that the most robust model for $S$. amethystinus has direct significant associations with B01 and B07 reflectances, temperature, total mixotrophic ciliates abundances and $S$. araucanus abundances, whereas it has inverse significant association between B02, B04 and B07 reflectances, and with O. naumanni abundances (Table 2). Finally, for $S$. araucanus the robust model had significant association between B04 reflectance and $S$. amethystinus abundances (Table 4).

\section{Discussion}

The obtained results would be similar to first descriptions of North Patagonian lakes of Argentina and Chile about the presence of $O$. naumanni, $S$. amethystinus and $S$. araucanus [4, 5]. The dominance of the all species in the second sampled period would be similar to the literature descriptions that mentioned the marked dominance of this species in southern summer (December, January, and February) [5], that would be explained probably to temperature increase. Although literature mentioned that mixotrophic ciliates graze on bacteria $[3,13]$, the literature published about bacterial abundances in North Patagonian lakes are very preliminary, and denotes differences in function to human intervention for Villarrica lake $[15,28]$. The marked differences in spectral properties in both lakes (Table 1), is agree with literature descriptions for a central Chilean lake with marked gradient of trophic status in different sites [28]. In this context, the marked associations of different ETM+ remote sensor bands between $S$. araucanus with the other two species would be due the pigmentation of the first specie that is blue-green, whereas $O$. naumanni and $S$. amethystinus have green-brown pigmentation [14, 29]. Also, $S$. araucanus is dominant in surface layers (epilimnion), due its marked photoprotective strategies, whereas $O$. naumanni and $S$. amethystinus prefers metalimnion due their vulnerability to natural solar radiation [5].

Similar results about the same mixotrophic ciliates species abundances and trophic interactions, has been described for Argentinean north Patagonian lakes [6, 7, 30-32]. The Argentinean lakes has more studies about interactions between bacteria and pyco-phytoplankton, for these lakes have descriptions of pyco-cianobacteria that are abundant in metalimnion zones [33] and other kind of bacteria [34, 35]. The results obtained for Argentinean lakes about mixotrophic ciliates, and ultraoligotrophic lakes would give support to the present 


\begin{tabular}{|c|c|c|c|c|c|c|c|c|c|c|c|c|c|}
\hline రิ & $\begin{array}{ll}2 & \overline{8} \\
\infty & 0 \\
0 & 0 \\
0 & 0\end{array}$ & & & & & & & & & & & & \\
\hline 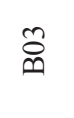 & $\begin{array}{ll}0 & \overline{8} \\
0 & 0 \\
0 & 0 \\
0 & 0 \\
0\end{array}$ & 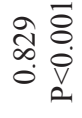 & & & & & & & & & & & \\
\hline 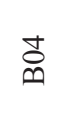 & 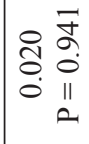 & 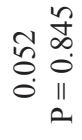 & 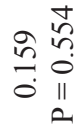 & & & & & & & & & & \\
\hline ڤ̊ & 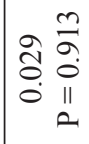 & 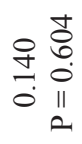 & 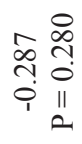 & 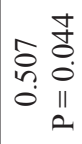 & & & & & & & & & \\
\hline ฉ̊ & 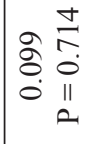 & 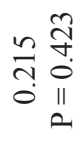 & 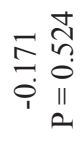 & 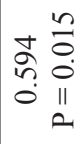 & 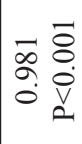 & & & & & & & & \\
\hline$\hat{\mathscr{m}}$ & 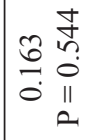 & 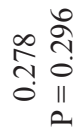 & 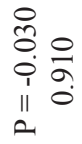 & 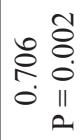 & $\mid \begin{array}{cc}\infty & \overline{8} \\
0 & 0 \\
0 & 0 \\
0 & 0 \\
0\end{array}$ & $\mid \begin{array}{cc}\vec{b} & \overline{0} \\
0 & 0 \\
0 & \bar{v} \\
0\end{array}$ & & & & & & & \\
\hline 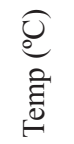 & 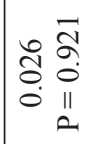 & 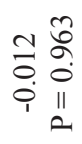 & 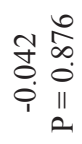 & 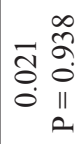 & 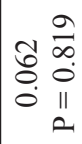 & 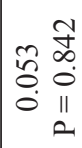 & $\begin{array}{cc}0 \\
0 \\
0 \\
0 \\
0 \\
0 & 0 \\
0 & 0 \\
0 & 0 \\
0\end{array}$ & & & & & & \\
\hline 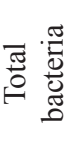 & 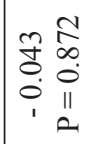 & 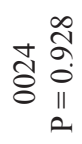 & 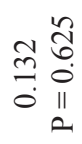 & 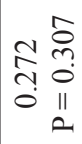 & 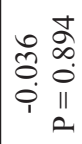 & 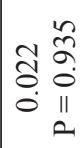 & 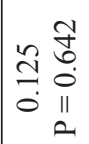 & 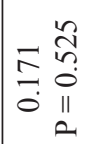 & & & & & \\
\hline $\begin{array}{c}\sigma_{1} \\
\vec{z}\end{array}$ & 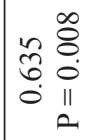 & 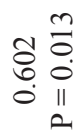 & 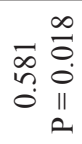 & 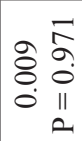 & 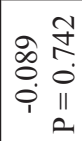 & 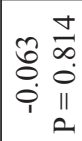 & 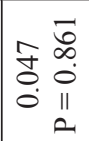 & 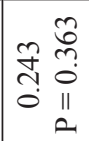 & 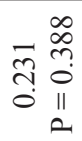 & & & & \\
\hline 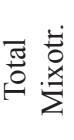 & $\begin{array}{ll}0 & \overline{8} \\
0 & 0 \\
0 & 0 \\
1 & 0 \\
1 & 0\end{array}$ & $\begin{array}{ll}8 & \overline{8} \\
0 & 0 \\
0 & 0 \\
1 & 0 \\
\end{array}$ & 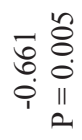 & 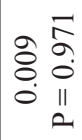 & 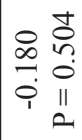 & 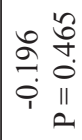 & 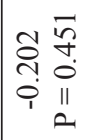 & 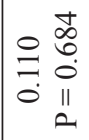 & 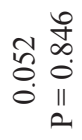 & 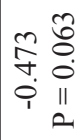 & & & \\
\hline 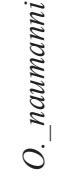 & $\begin{array}{ll}i & \overline{8} \\
h & 0 \\
i & 0 \\
1 & 0\end{array}$ & 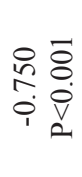 & 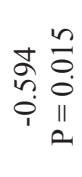 & $\begin{array}{ll}\vec{F} & \infty \\
0 & \infty \\
0 & 0 \\
0 & 0 \\
1 & \|\end{array}$ & 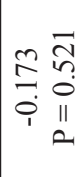 & 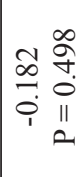 & 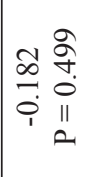 & 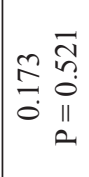 & 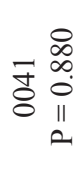 & 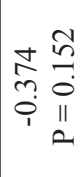 & $\begin{array}{ll}n & \overline{8} \\
0 & 0 \\
0 & 0 \\
0 & v \\
0\end{array}$ & & \\
\hline 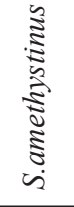 & $\begin{array}{ll}0 & \overline{8} \\
0 & 0 \\
0 & 0 \\
1 & 0 \\
1\end{array}$ & 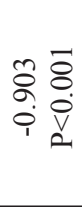 & $\begin{array}{l}\overrightarrow{\hat{\sigma}} \overline{0} \\
0 \\
i \\
i\end{array}$ & 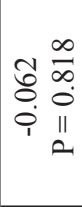 & 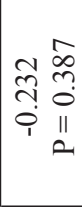 & 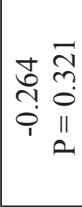 & 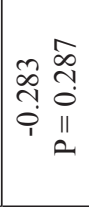 & $\begin{array}{cc}2 & 2 \\
0 & 0 \\
0 & 0 \\
0 & 11 \\
2\end{array}$ & 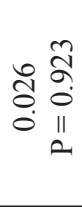 & 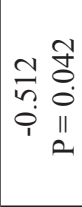 & 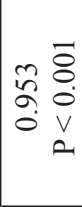 & $\begin{array}{ll}n & \overline{8} \\
2 & 0 \\
0 & 0 \\
0 & v \\
2\end{array}$ & \\
\hline 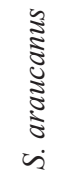 & $\begin{array}{ll}c & \overline{8} \\
\infty & 0 \\
0 & 0 \\
1 & 0 \\
1 & 0\end{array}$ & $\begin{array}{l}\simeq \overrightarrow{0} \\
\infty \\
0 \\
i \\
i \\
0\end{array}$ & 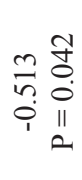 & 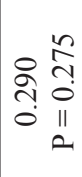 & $\begin{array}{cc}0 & 0 \\
y & 0 \\
0 & 0 \\
0 & 11 \\
1 & 11\end{array}$ & 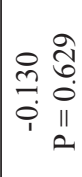 & 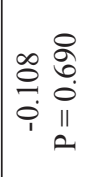 & 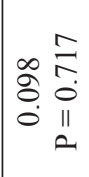 & 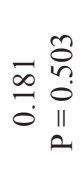 & $\begin{array}{cc}\infty & n \\
\infty & \tilde{2} \\
0 & 0 \\
0 & 0 \\
0 & 11 \\
1 & 11\end{array}$ & $\begin{array}{rr}a & \overline{8} \\
\infty & 0 \\
0 & 0 \\
0 & v \\
& b\end{array}$ & $\begin{array}{ll}0 & \overline{8} \\
0 & 0 \\
0 & 0 \\
0 & v \\
0\end{array}$ & $\begin{array}{ll}r & \bar{a} \\
\dot{b} & 0 \\
0 & \dot{v} \\
0 & v \\
2\end{array}$ \\
\hline & $\vec{\varnothing}$ & రิ & ồ & d & oे & ¿े & $\ddot{\emptyset}$ & 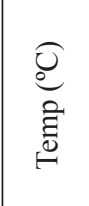 & 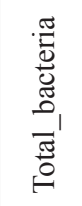 & $\bar{z}$ & 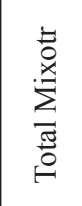 & 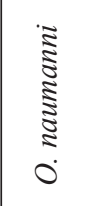 & 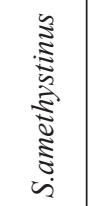 \\
\hline
\end{tabular}


Table 3. Contribution of considered variables for PCA.

\begin{tabular}{|c|c|c|}
\hline & Axis 1 & Axis 2 \\
\hline B01 & -0.375 & 0.087 \\
\hline B02 & -0.380 & 0.027 \\
\hline B03 & -0.305 & 0.176 \\
\hline B04 & -0.037 & -0.392 \\
\hline B05 & -0.083 & -0.506 \\
\hline B06 & -0.103 & -0.516 \\
\hline B07 & -0.121 & -0.507 \\
\hline Temp $\left({ }^{\circ} \mathrm{C}\right)$ & 0.021 & -0.041 \\
\hline Total_bacteria & $<-0.001$ & -0.061 \\
\hline Chlorophyll_a & -0.242 & 0.111 \\
\hline Total Mixotrophic & 0.377 & -0.032 \\
\hline O. naumanni & 0.347 & -0.021 \\
\hline S. amethystinus & 0.381 & 0.006 \\
\hline S. araucanus & 0.346 & -0.09 \\
\hline
\end{tabular}

results observed for Caburgua lake, nevertheless, the available methodology to determine bacterial abundances is more developed for Argentinean lakes than for Chilean lakes, and in the present status the field study of the role of bacterial in Chilean lakes would be uncertain [3]. The trophic interactions that involve mixotrophic ciliates, reported that this group together crustacean zooplankton would graze on bacteria, such as been observed for Argentinean lakes [36], and in this scenario, it would have direct association between mixotrophic ciliates with crustacean zooplankton such as been observed for Argentinean Patagonian lakes $[34,36]$. Similar results have been observed for marine environments [37, 38-40]. Also, important topic about mixotrophic ciliates, is related with phytoplankton decreasing, this result was observed in the present study for Caburgua Lake, and also was described for Baikal lake [41] and Alpine lakes [42]. In this context, it has been reported for Argentinean Patagonia and for Alpine lakes, that it is possible found abundant mixotrophic ciliates under presence of glacier sediments that would affect water transparency affecting the phytoplankton activity, and enhancing mixotrophic ciliates activity

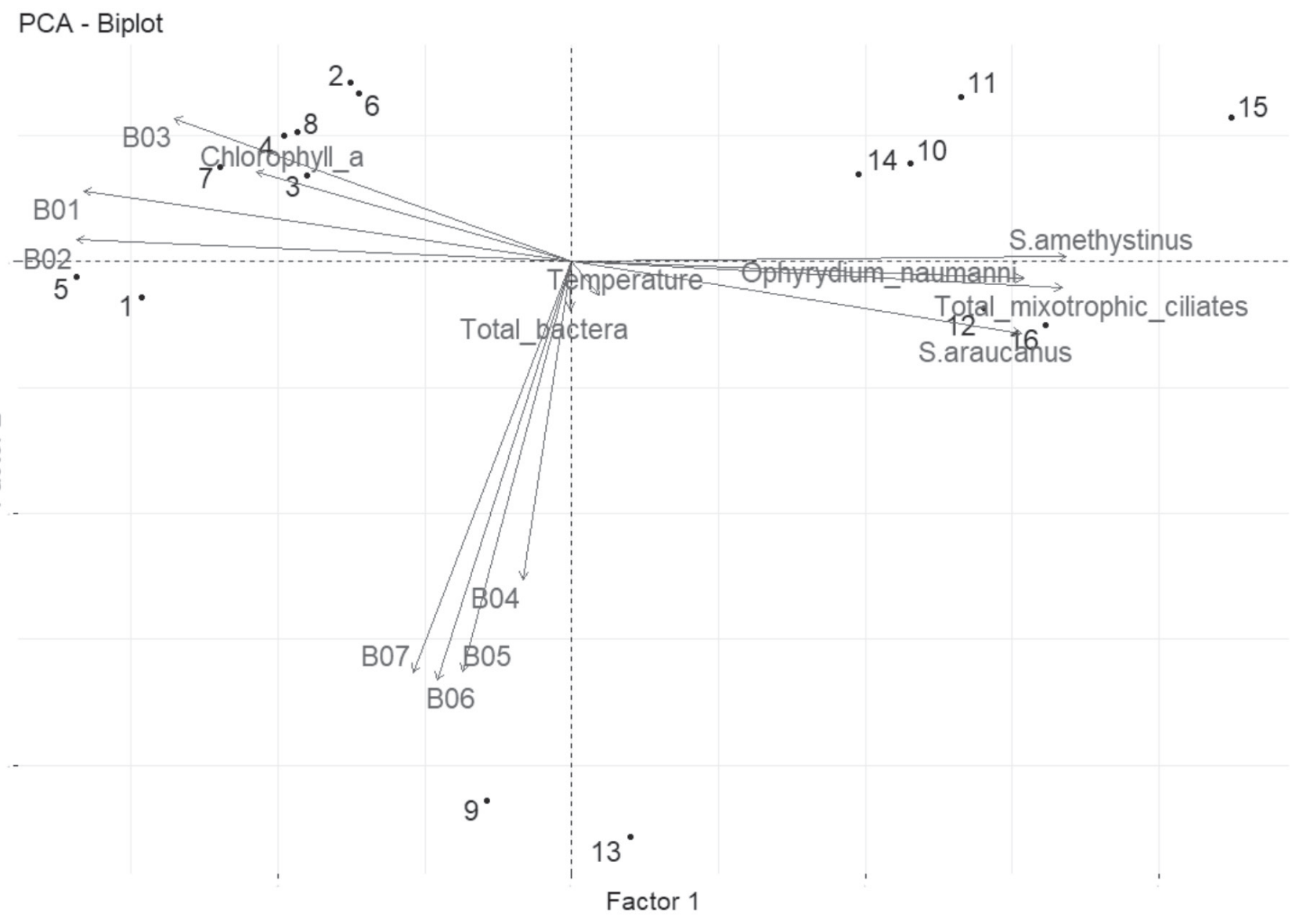

Fig. 2. Results of PCA for sites and variables included in the present study (Legend for sites: $1=$ Villarrica North littoral, November; 2 = Villarrica centre, November; 3 = Villarrica port November; 4 = Villarrica La Poza Pucon bay November; $5=$ Villarrica North littoral, December; 6 = Villarrica centre, December; $7=$ Villarrica port, December; $8=$ Villarrica La Poza Pucon bay, December; $9=$ Caburgua 1, November; 10 = Caburgua 2 = November; $11=$ Caburgua 3, November; $12=$ Caburgua 4, November; $13=$ Caburgua 1, December; 14 = Caburgua 2, December; 15 = Caburgua 3, December; 16 = Caburgua 4, December). 
Table 4. Results of multiple regression analysis for mixotrophic ciliates species reported in the present study.

\begin{tabular}{|c|c|c|c|c|}
\hline \multicolumn{5}{|c|}{ Ophyridium naumanni } \\
\hline & Estimate & Standard error & $\mathrm{T}$ value & $P$ value \\
\hline Intercept & 6.3126 & 3.4459 & 1.832 & 0.116 \\
\hline B01 & 377.484 & 110.786 & 3.407 & $0.143^{*}$ \\
\hline B02 & -405.256 & 140.924 & -2.876 & $0.028^{*}$ \\
\hline B04 & -552.330 & 94.589 & -5.839 & $0.001 *$ \\
\hline B06 & -266.166 & 92.176 & -2.888 & $0.027^{*}$ \\
\hline B07 & 985.984 & 255.852 & 3.854 & $0.008^{*}$ \\
\hline Temperature & 0.044 & 0.016 & 2.617 & $0.039^{*}$ \\
\hline Total mixotrophic & 0.912 & 0.030 & 29.586 & $<0.001 *$ \\
\hline S. amethystinus & -1.762 & 0.148 & -11.862 & $<0.001 *$ \\
\hline S. araucanus & 0.279 & 0.107 & 2.586 & $0.004 *$ \\
\hline \multicolumn{5}{|c|}{ Residual standard error: 0.180 , on 6 degrees of freedom, multiple $\mathrm{R}^{2}=0.998 ;$ adjusted $\mathrm{R}^{2}=0.996 ; \mathrm{F}_{(6 ; 9 ; \alpha=0.05)}=<0.001$} \\
\hline \multicolumn{5}{|c|}{ Stentor amethystinus } \\
\hline & Estimate & Standard error & T value & P value \\
\hline Intercept & 0.399 & 0.174 & 2.284 & 0.062 \\
\hline B01 & 0.021 & 0.546 & 4.047 & $0.006^{*}$ \\
\hline B02 & -0.024 & 0.685 & -3.550 & $0.012 *$ \\
\hline B04 & -0.031 & 0.451 & -6.962 & $<0.001 *$ \\
\hline B06 & -0.015 & 0.487 & -3.140 & $0.020^{*}$ \\
\hline B07 & -0.056 & 0.013 & 4.382 & $0.004 *$ \\
\hline Temperature & 0.024 & 0.009 & 2.503 & $0.046^{*}$ \\
\hline Total mixotrophic & 0.501 & 0.037 & 13.554 & $<0.001^{*}$ \\
\hline O. naumanni & -0.544 & 0.046 & -11.862 & $<0.001^{*}$ \\
\hline S. araucanus & -0.165 & 0.054 & 2.975 & $0.024 *$ \\
\hline \multicolumn{5}{|c|}{ Residual standard error: 0.100 , on 6 degrees of freedom, multiple $\mathrm{R}^{2}=0.998 ;$ adjusted $\mathrm{R}^{2}=0.996 ; \mathrm{F}_{(6 ; ; ; \alpha=0.05)}=<0.001$} \\
\hline \multicolumn{5}{|c|}{ Stentor araucanus } \\
\hline & Estimate & Standard error & T value & P value \\
\hline Intercept & -9.960 & 2.925 & -3.404 & $0.004 *$ \\
\hline B04 & 361.285 & 104.298 & 3.464 & $0.004^{*}$ \\
\hline S. amethystinus & 1.061 & 0.119 & 8.902 & $<0.001 *$ \\
\hline
\end{tabular}

[43]. In this scenario, if the first observations denoted for Patagonian lakes the associations between spectral properties and zooplankton composition [15-18], these results would be applicable to mixotrophic ciliates such as been observed in the present study.

The use of remote sensing techniques, for water quality studies in lakes [44], proposed marked associations in spectral properties and chlorophyll concentration [44-51]. In this context would have marked differences in watercolour due to water quality that can be detectable using remote sensing techniques $[52,53]$. Also, it was proposed the use of remote sensing techniques for determine potential associations with cyanobacterial pigments in lakes [54-56]. The exposed results about associations between differences in water quality with their respective correspondence in spectral images, would be similar to the observed results in the present study. Also, in this scenario, the present results it would be possible detect differences within a same lake at large spatial scales (ten or more kilometres), that 
can be detectable using remote sensing techniques $[15$, 57].

The exposed results revealed the presence of differences between water qualities, specifically chlorophyll concentration, between two lakes, and within each lake [15]. Nevertheless, the integration of limnological descriptions and remote sensing techniques for Chilean lakes has been described only for Vichuquén lake $\left(34^{\circ} 48^{\prime} 42^{\prime \prime} \mathrm{S} ; 72^{\circ} 02^{\prime} 57^{\prime \prime} \mathrm{W}\right)$, that is a coastal central Chilean lake, with marked human intervention in their surrounding basin, and it was possible propose a predictive model based in LANDSAT 8 OLI sensor images [57]. In this scenario it would be possible use remote sensing techniques for predict water quality in northern Patagonian lakes.

\section{Acknowledgments}

The present study was funded by projects VIPUCT 2017RE-PR-06 and MECESUP UCT 0804. Also, it recognized the important logistic support of Chilean Navy (Villarrica Port Commandance), Mr. Pablo Saavedra for his valuable logistical support, finally the authors express their gratitude to M.I. and S.M.A for their valuable help in improving the manuscript.

\section{Conflict of Interest}

The authors declare no conflict of interest.

\section{References}

1. THOMASSON K. Araucanian Lakes. Acta Phytogeographica Suecica 47, 1, 1963.

2. CAMPOS H. Limnological study of Araucanian lakes (Chile). Verhandlungen Internationale Vereinigung für Angewandte Limnologie, 22, 1319, 1984.

3. WÖLFL S. Untersuchungen zur Zooplanktonstruktur einschliesslich der mikrobiellen Gruppen unter besonderer Berücksichtigung der mixotrophen Ciliaten in zwei Südchilenischen Andenfußseen: 1-242. (Doctoral Thesis, Universität Konstanz). 1995.

4. WOELFL S. The distribution of large mixotrophic ciliates (Stentor) in deep North Patagonian lakes (Chile): First results. Limnologica, 37: 28, 2007.

5. WOELFL S., GARCIA P., DUARTE C. Chlorella-bearing ciliates (Stentor, Ophrydium) dominate in an oligotrophic, Deep, North Patagonian lake (Lake Caburgua, Chile). Limnologica 40: 134, 2010.

6. MODENUTTI B., BALSEIRO E. Mixotrophic ciliates in North-Patagonian Andean lakes: stoichiometric balances in nutrient limited environments. Limnetica, 39, 263, 2020.

7. MODENUTTI B. Mixotrophy in Argentinean freshwaters. In: G. Tell, I. Izaguirre \& I. O'Farrell (Eds). Freshwater phytoplankton of Argentina. Advances of Limnology 65, 359, 2014.

8. SOTO D. Oligotrophic patterns in southern Chile lakes: the relevance of nutrients and mixing depth. Revista Chilena de Historia Natural, 75, 377, 2002.
9. DE LOS RÍOS-ESCALANTE P., SOTO D., ACEVEDO P., SANTANDER MASSA R. Zooplankton communities in bays with different trophic status in Llanquihue lake (41으, Chile). Brazilian Journal of Biology, 77, 469, 2017.

10. WOELFL S., VILlalobOS L., PARRA O., Trophic parameters and method validation in Lake Riñihue (North Patagonia: Chile) from 1978 through 1997. Revista Chilena de Historia Natural, 76, 459, 2003.

11. DE LOS RÍOS P., WOELFL S., SOTO C. Experimental evidence from crustacean zooplankton grazing activity on mixotrophic ciliates. Animal Biology, 69, 259, 2019.

12. KAMJUNKE N., KRAMPS M., CHÁVEZ S., WOELFL S. Composition of large Chlorella-bearing ciliates (Stentor) by Mesocyclops araucanus in North Patagonian lakes. Journal of Plankton Research, 34, 922, 2012.

13. KAMJUNKE N., VOGT B., WOELFL S. Trophic interactions of the pelagic ciliate Stentor spp., in North Patagonian lakes. Limnologica 39, 107, 2009.

14. WOELFL S., GELLER W. Chlorella-bearing ciliates dominate in an oligotrophic North Patagonian lake (Lake Pirehueico, Chile): abundance, biomass and symbiotic photosynthesis. Freshwater Biology 47, 231, 2002.

15. DE LOS RÍOS P., CONTRERAS A., LARA G., LATSAGUE M., ESSE C. First reports of associations between spectral properties, chlorophyll, bacterial and zooplankton in two Chilean North Patagonian lakes (Villarrica and Caburgua, $38^{\circ} \mathrm{S}$, Araucania region, Chile). Journal of King Saud University-Sciences, 32, 3167, 2020.

16. DE LOS RÍOS-ESCALANTE P., QUINAN E., ACEVEDO P. Crustacean zooplankton communities in Lake General Carrera $\left(46^{\circ} \mathrm{S}\right)$ and their possible association with optical properties. Crustaceana, 86, 506, 2013.

17. DE LOS RÍOS-ESCALANTE P., ACEVEDO P. First observations on zooplankton and optical properties in a glacial North Patagonian lake (Tagua Tagua lake, $41^{\circ} \mathrm{S}$ Chile). Polish Journal of Environmental Studies, 25, 453, 2016.

18. DE LOS RÍOS-ESCALANTE P,. ACEVEDO P. First observations of Boeckella michaelseni Mrázek 1901 and optical properties of a Central Patagonian lake. Polish Journal of Environmental Studies, 25, 1781, 2016.

19. AMERICAN PUBLIC HEALTH ASSOCIATION, (APHA). Standard Methods for analysis of water and wastewater. American Public Health Association, Washington, DC. U.S.A., 1989.

20. STRICKLAND J.D., PARSONS R. A practical handbook of seawater analysis. Fisheries Review Board Canadian Bulletin, 167, 1, 1972.

21. VAN DE VYVER E., VAN WICHELEN J., VANORMELINGEN P., VAN NIEEWENHUYZE W., DAVELOOSE I., DE JONG R., DE BLOCK R., URRUTIA R., TYTGAT B., VERLEYEN E., VYVERMAN W. Variation in phytoplankton pigment composition in relation to mixing conditions in temperate South-Central Chilean lakes. Limnologica, 79, 125715, 2019.

22. CHAVEZ P. Image based atmospheric corrections revisited and improved. Photogrammetric Engineering and Remote Sensing 61, 1025, 1996.

23. R DEVELOPMENT CORE TEAM, R: A language and environment for statistical computing. $\mathrm{R}$ foundation for statistical computing, Vienna, Austria, 2009.

24. HARRELL, F.E. Package "Hmisc". Available from:

25. https://cran.r-project.org/web/packages/Hmisc/Hmisc.pdf 2016. (Accessed $24^{\text {th }}$ April 2020).

26. KASSAMBARA A., MUNDT F., Factoextra: extract and visualize the results of multivariate data analyses. 
R package version 1.0.5. Available from: https://CRAN.Rproject.org/package $=$ factoextra. 2016. (Accessed $24^{\text {th }}$ April 2020).

27. WICKHAM H. ggplot2: Elegant Graphics for Data Analysis. Springer-Verlag New York. ISBN 978-3-31924277-4, https://ggplot2.tidyverse.org. 2016. (Accessed 24th April 2020).

28. ZAR J.H. Biostatistical Analysis. Prentice Hall, New Jersey, Upper Saddle River, U.S.A. 1999.

29. BROWN A., ZIMMERMAN R. Bacteriological analysis of lake Villarrica, Chile and some of its affluents. Medio Ambiente, 13, 63, 2000.

30. FOISSNER W., WÖLFL S. Revision of the genus Stentor Oken (Protozoa, Ciliophora) and description of $S$. araucanus nov. spec, from South American lakes. Journal of Plankton Research, 16, 255, 1994.

31. MODENUTTI B.E., WOLINSKI L., SOUZA M.S., BALSEIRO M.S. When eating a prey is risky: Implications for predator diel vertical migration. Limnology and Oceanography. 62, 939, 2018.

32. MODENUTTI B., BALSEIRO E., CALLIERI C., BERTONI R. Light vs food supply as factors modulating niche partitioning in two pelagic mixotrophic ciliates. Limnology and Oceanography 53, 446, 2008.

33. CORNO G., MODENUTTI B., CALLIERI C., BALSEIRO E., BERTONI R., CARAVATI E. Bacterial diversity and morphology in deep ultraoligotrophic Andean lakes: the role of UVR on vertical distribution. Limnology and Oceanography 54, 1098, 2009.

34. CALLIERI C., COCI M., CORNO G., MACEK M., MODENUTTI B., BALSEIRO E., BERTONI R. Phylogenetic diversity of non-marine picocyanobacteria. FEMS Microbiology Ecology 85, 293, 2013.

35. BASTIDAS-NAVARRO M., BALSEIRO E., MODENUTTI B. Bacterial community structure in Patagonian Andean lakes above and below timberline: From community composition to community function. Microbial Ecology, 68, 528, 2014.

36. BASTIDAS-NAVARRO M., MODENUTTI B., CALLIERI C., BERTONI R., BALSEIRO E. Balance between primary and bacterial production in North Patagonian shallow lakes. Aquatic Ecology, 43, 867, 2009.

37. MODENUTTI B.E., BALSEIRO E.G., QUEIMALINOS C.P. Ciliate community structure in two South Andean lakes: the effect of lake water on Ophrydium naumanni distribution. Aquatic Microbial Ecology, 21, 299, 2000.

38. PTACNIK R., GOMES A., ROYER S.-J., BERGR S.A., CALBET A., NEJSTGAARD J.C., GASOL J.M., ISARI S., MOORTHI S.D., PTACNIKOVA R., STRIEBEL M., SAZHIN A.F., TSAGARAKI T.M., ZERVOUDAKI S., ALTOJA K., DIMITRIOU P.D., LAAS P., GASIHAN A., MARTÍNEZ R.A., SCHABHÜTTI S., SANTI I., SOUSONI D., PITTA P. A light-induced shortcut in the planktonic microbial loop. Scientific Reports 6, 29286, 2016.

39. FISHER R., GIEBEL H.-A., HILLEBRAND H., PTACNIK R. Importance of mixotrophic bacterivory can be predicted by light and loss rates. Oikos 126, 713, 2017.

40. MOORTHI S.D., PTACNIK R., SANDERS R.W., FISHER R., BUSH M., HILLEBRAND H. The functional role of planktonic mixotrophs in altering seston stoichiometry. Aquatic Microbial Ecology, 79, 235, 2017.

41. STIBOR H., STOCKENREITER M., NEJSTGAARD J.C., PTACNIK R., SOMMER U. Trophic switches in pelagic systems. Current Opinion in System Biology, 13, 108, 2019.
42. BONDARENKO N.A., OZERSKY T., OBOLKINA L.A., TIKHONOVA IV, SOROKOVIKOVA E.G., SAKIRKO M.V., POTAPOV S.A., BLINOV V.V., BELYJH Recent changes in the spring microplankton of Lake Baikal, Russia. Limnologica, 75, 19, 2019.

43. KAMMERLANDER B., KOINIG K., ROTT E., SOMMARUGA R., TARTAROTTI B., TRATTNER F., SONNTAG B. Ciliate community structure and interactions within the planktonic food web in two alpine lakes of contrasting transparency. Freshwater Biology, 61, 1950, 2016

44. BASTIDAS-NAVARRO M., MARTYNIUK N., BALSEIRO E., MODENUTTI B. Effect of glacial lake outburst floods on the light climate in an Andean Patagonian lake: implications for planktonic phototrophs. Hydrobiologia 816, 39, 2018.

45. MALENOVSKY Z., ROTT H., CIHLAR J., SCHAEPMAN M.E., GARCÍA-SANTOS G., FERNANDES R., BERGER M. Sentinels for science: potential of Sentinel-1, -2 and -3 missions for scientific observations of ocean, cryosphere and land. Remote Sensing of Environment, 120, 91, 2012.

46. ATZBERGER C., RICHTER K. Spatially constrained inversion of radiate transfer models for improved LAI mapping from future Sentinel-2 imagery. Remote Sensing of Environment, 120, 208, 2012.

47. KALLIO K., KOPONEN S., YLÖSTALO P., KERVINEN M., PYHÄLAHTI ATTILA J. Validation of MERIS spectral inversion processors using reflectance, IOP and water quality measurements in boreal lakes. Remote Sensing of Environment, 157, 147, 2015.

48. PALMER S.C.J. Remote sensing of inland waters: challenges, progress and future directions. Remote Sensing of Environment, 157, 1, 2015.

49. PALMER S.C.J., HUNTER P.D., LANKESTER T., HUBBARD S., SPYRAKOS E., TYLER A.N., PRESSING M., HORVÁTH H., LAMB A., BALZTER H., TÓTH V.R. Validation of Envisat MERIS algorithms for chlorophyll retrieval in a large, turbid and optically-complex shallow lake. Remote Sensing of Environment, 157, 158, 2015.

50. STERCKX S., KNAEPS S., KRATZER S., RUDDICK K. SIMilarity Environment Correction (SIMEC) applied to MERIS data over inland and coastal waters. Remote Sensing of Environment, 157, 96, 2015.

51. STRATOULIAS D., BALZTER H., ZLINSZKY A., TÓTH V.R. Assesment of ecophysiology of lake shore reed vegetation based on chlorophyll fluorescence, field spectroscopy and hyperspectral airborne imagery. Remote Sensing of Environment, 157, 72, 2015.

52. ESSE C., FUSTOS I., GONZALEZ K., AGUAYO C., ENCINA-MONTOYA F., FIGUEROA D., LARA G., NAVARRO C. Spectral characterization of Didymosphenia geminata under laboratory conditions: bases for a monitoring and early warning system in river systems of south central Chile. Management of Biological Invasions, 9, 85, 2018

53. SALAMA M., VERHOEF W. Two-stream remote sensing model for water quality mapping: 2SeaColor. Remote Sensing of Environment, 157, 111, 2015.

54. SANDER L.A., BARBOSA C.C.F., DE MOREAES E.M.L., DE MORAES C. Implications of scatter corrections for absorption measurements on optical closure of Amazon floodplain lakes using the Spectral Absorption and Attenuation Metter (AC-S-WETLabs). Remote Sensing of Environment, 157, 123, 2015. 
55. LI L., LI L., SONG K. Remote sensing of freshwater cyanobacteria: an extended IOP Inversion Models of Inland Waters (IIMIW) for portioning absorption coefficient and estimating phycocyanin. Remote Sensing of Environment, 157, 9, 2015.

56. LUNETTA R.S., SCHAEFFER B.A., STUMPF R.P., KEITH D., JACOBS S.A., MURPHY M.S. Evaluation of cyanobacteria cell count detection derived from MERIS imagery across the eastern USA. Remote Sensing of Environment, 157, 24, 2015.
57. OYAMA Y., MATSUSHITA B., FUKUSHIMA T. Distinguishing Surface cyanobacterial blooms and aquatic macrophytes using Landsat/TM and ETM + shortwave infrared bands. Remote Sensing of Environment, 15, 35, 2015.

58. BRICEÑO I., PEREZ W., SAN MIGUEL D., RAMOS S. Determinación de calidad de agua en el lago Vichuquén con imágenes de satélite Landsat 8, sensor OLI año 2016, Chile. Revista de Teledetección, 52, 67, 2018. 
